\title{
Epidemiology of hepatitis B virus infection among recyclable waste collectors in central Brazil
}

\author{
Tamíris Augusto Marinho ${ }^{[1]}$, Carmen Luci Rodrigues Lopes ${ }^{[2]}$, Sheila Araújo Teles ${ }^{[2],}$ \\ Marcos André de Matos ${ }^{[2]}$, Márcia Alves Dias de Matos ${ }^{[1]}$, Aline Garcia Kozlowski ${ }^{[1]}$, \\ Marina Pedroso de Oliveira ${ }^{[1]}$, Ágabo Macêdo da Costa e Silva ${ }^{[1]}$ \\ and Regina Maria Bringel Martins ${ }^{[1]}$
}

[1]. Instituto de Patologia Tropical e Saúde Pública, Universidade Federal de Goiás, Goiânia, GO. [2]. Faculdade de Enfermagem, Universidade Federal de Goiás, Goiânia, GO.

\begin{abstract}
Introduction: The collection of recyclable waste materials is a widespread activity among the urban poor. Today, this occupation attracts an increasingly large number of individuals. Despite its economic and environmental importance, this activity is associated with unsafe and unhealthy working conditions. The aim of this study was to investigate the seroepidemiological profile of hepatitis $B$ virus (HBV) infection in a population of recyclable waste collectors in central Brazil. Methods: Recyclable waste collectors from all 15 recycling cooperatives in Goiânia City were invited to participate in the study. The participants $(n=431)$ were interviewed and screened for hepatitis B surface antigen (HBsAg) and antibodies against HBsAg (anti-HBs) and hepatitis B core antigen (anti-HBc) by enzyme-linked immunosorbent assay (ELISA). HBsAg- and anti-HBc-positive samples were tested for HBV DNA and genotyped. Results: The overall prevalence of HBV infection (HBsAg- and/or anti-HBc-positive) was 12.8\%. An age over 40 years and illicit drug use were associated with HBV infection. HBV DNA was detected in 2/3 HBsAg-positive samples and in 1/52 anti-HBc-positive/HBsAg-negative samples (an occult HBV infection rate of 1.9\%), in which the genotypes/subgenotypes $\mathrm{A} / \mathrm{A} 1, \mathrm{D} / \mathrm{D} 3$ and F/F2 were identified. Only $12.3 \%$ of the recyclable waste collectors had serological evidence of previous HBV vaccination. Conclusions: These findings highlight the vulnerability of recyclable waste collectors to HBV infection and reinforce the importance of public health policies that address the health and safety of this socially vulnerable population.
\end{abstract}

Keywords: Hepatitis B. Recyclable waste collectors. Prevalence. Associated factors. Genotypes.

\section{INTRODUCTION}

Hepatitis B virus (HBV) infection represents the causative agent of global but preventable liver disease and remains an important public health problem, especially in developing countries. HBV infection can be transmitted through unprotected sexual intercourse, contact with contaminated blood or motherto-child transmission, and this infection can lead to chronic liver disease, which affects more than 240 million individuals worldwide. Chronic carriers constitute a potential reservoir of $\mathrm{HBV}$ and are at increased risk of developing liver cirrhosis or hepatocellular carcinoma ${ }^{1,2}$.

Hepatitis B surface antigen (HBsAg) represents an established serological marker for diagnosing acute or chronic HBV infection. HBV deoxyribonucleic acid (DNA) has, however, been detected in the serum and/or liver of individuals

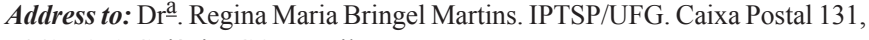
74605-050 Goiânia, GO, Brasil.

Phone: 5562 3209-6129

e-mail: rbringel.iptsp.ufg@gmail.com

Received 6 September 2013

Accepted 30 January 2014
}

without detectable HBsAg levels. This peculiar form of chronic infection is referred to as an occult HBV infection and represents an HBV transmission risk, despite the low levels of detectable HBV DNA ${ }^{3}$. Based on sequence divergence of $8 \%$ or greater throughout the entire genome, HBV has been classified into 10 genotypes (A-J), which have defined geographic distributions $\mathrm{s}^{4}$.

The collection of recyclable waste materials is a widespread activity among the urban poor. In Brazil, selective waste collection is conducted by catadores (pickers), individuals who work either on an individual, informal and autonomous basis or in organized recycling cooperatives or associations. These pickers collect, separate, classify and sell all types of recyclable waste. In 2002, this job was regulated by the Brazilian Occupational Classification. Today, this occupation attracts an increasingly large number of individuals in urban areas. There are an estimated 1 million recyclable waste collectors in Brazil ${ }^{5}$. Despite its economic and environmental importance, this occupation is associated with unsafe and unhealthy working conditions. In addition, recyclable waste collectors have a lifestyle that is characterized by socioeconomic exclusion and stigmatization $^{6-12}$.

Occupational exposure to waste is a possible risk factor for $\mathrm{HBV}$ infection, and injury with needle sticks/sharp instruments could be associated with this infection ${ }^{13}$. A high prevalence of HBV infection (34.4\%) was found among recyclable waste 
collectors in Santos City, Brazil ${ }^{14,15}$, but no other data regarding $\mathrm{HBV}$ infection in this emerging urban population are available. Therefore, the aim of this study was to investigate the prevalence of and factors associated with HBV infection and to identify the genotypes of this virus circulating in a population of recyclable waste collectors in central Brazil.

\section{METHODS}

A cross-sectional study was performed in a population of recyclable waste collectors in Goiânia (a city with approximately $1,300,000$ inhabitants), the capital of the State of Goiás, central Brazil. Since 2008, Goiânia has been engaged in the implementation of the Programa Goiânia Coleta Seletiva recycling program. This program focuses on integrating actions between collectors and the municipal government, which provides the collection of recyclables from every household. The rise in household recyclable collection has led to the creation of 15 cooperatives.

Between April 2010 and May 2011, recyclable waste pickers were recruited from all recycling cooperatives, and all individuals were invited to participate in this study. The study population consisted of 431 individuals. These participants represented $99.8 \%$ of the recyclable waste pickers who were participating in the cooperatives during the study period. Participation was voluntary. Written informed consent was obtained from all participants prior to the start of the study. The participants were interviewed to gather sociodemographic (age, gender, race/ethnicity, marital status, schooling and monthly income) and professional information and information on other risky behaviors (time spent as a recyclable waste collector, number of occupational accidents, history of blood transfusions, tattoos, illicit drug use, lifetime number of sexual partners, inconsistent or no condom use, incidence of previous sexually transmitted diseases [STDs] and incarceration) and their HBV vaccination status. All interviews were conducted in private locations at the participants' respective recycling cooperatives.

Blood was collected $(10 \mathrm{ml})$ from all participants, and serum samples were tested by enzyme-linked immunosorbent assay (ELISA) for the presence of HBsAg (Hepanostika HBsAg Ultra, bioMérieux, Boxtel, the Netherlands), antibodies against hepatitis B core antigen (anti-HBc) (Hepanostika anti-HBc UniForm, bioMérieux) and antibodies against HBsAg (anti-HBs) (Bioelisa anti-HBs, Biokit, Barcelona, Spain). HBsAg-positive samples were assayed for hepatitis B e antigen ( $\mathrm{HBeAg}$ ) and antibodies against $\mathrm{HBeAg}$ (anti-HBe) (Eti-Ab-Ebk Plus, Diasorin, Italy). DNA was extracted from HBsAg- and antiHBc-positive samples as previously reported ${ }^{16}$. The pre-S/S genome region was amplified using a semi-nested polymerase chain reaction $(\mathrm{PCR})^{17}$, and the resulting amplicons were genotyped by nucleotide sequence analysis of the $\mathrm{S}$ region ${ }^{18}$.

HBV prevalence was estimated using a $95 \%$ confidence interval $(95 \% \mathrm{CI})$. Initially, a bivariate analysis was performed to determine the relationship between the dependent variable (the prevalence of HBV) and each independent variable, yielding prevalence ratios and respective $95 \%$ CIs. Variables with $\mathrm{p}<0.10$ were included in multivariate Poisson regression models. All analyses were performed using the Stata Statistical Package v. 11.

\section{Ethical considerations}

The protocol used in the present study was approved by the Ethical Committee of the Federal University of Goiás (Protocol Number: 002/2010).

\section{RESULTS}

The population of recyclable waste collectors studied herein was primarily composed of females $(62.4 \%)$. The mean age was $36.9 \pm 13.6$ years. The majority of the participants were non-Caucasian (79.4\%) and married (48.7\%), had received nine or fewer years of formal education (elementary school in Brazil, 78.7\%) and reported a monthly income of US\$ 300 or less (52.7\%).

Of 431 recyclable waste collectors, 55 (12.8\%; 95\% CI: 9.8-16.2) had been exposed to HBV (anti-HBc positive). Three $(0.7 \%)$ of these individuals were HBV carriers (HBsAg positive). Forty-two had been infected and had developed natural immunity (anti-HBc and anti-HBs positive), and 10 were anti$\mathrm{HBc}$ positive only. Fifty-three (12.3\%) individuals were positive only for anti-HBs, suggesting that they had been vaccinated against HBV. In addition, most (74.9\%) of the population studied was susceptible to HBV infection (Table 1).

TABLE 1 - Prevalence of hepatitis B virus serological markers in 431 recyclable waste collectors in Goiânia-Goiás, central Brazil, 2010-2011.

\begin{tabular}{lccc}
\hline HBV markers & Number & Percentage & $95 \%$ CI \\
\hline Any HBV exposure marker & 55 & 12.8 & $(9.8-16.2)$ \\
Anti-HBc/HBsAg & 3 & 0.7 & $(0.2-2.2)$ \\
Anti-HBc/anti-HBs & 42 & 9.8 & $(7.2-12.8)$ \\
Anti-HBc only & 10 & 2.3 & $(1.2-4.4)$ \\
Immunized (anti-HBs only) & 53 & 12.3 & $(9.4-15.7)$ \\
Susceptible & 323 & 74.9 & $(70.5-78.9)$ \\
\hline
\end{tabular}

95\% CI: 95\% confidence interval; HBV: hepatitis B virus; anti-HBc: antibodies against hepatitis B core antigen; HBsAg: hepatitis B surface antigen; anti-HBs: antibodies against HBsAg.

As shown in Table 2, an age over 40 years, a low schooling level, a history of incarceration and previous STDs were significantly associated with HBV infection $(p<0.05)$. In addition to illicit drug use $(\mathrm{p}=0.09)$ and unprotected sex with multiple partners $(\mathrm{p}=0.06)$, these variables were included in a multivariate Poisson regression model. An age over 40 years and illicit drug use were independently associated with HBV infection. 
TABLE 2 - Variables associated with hepatitis B virus infection in recyclable waste collectors in Goiânia-Goiás, central Brazil, $2010-2011$.

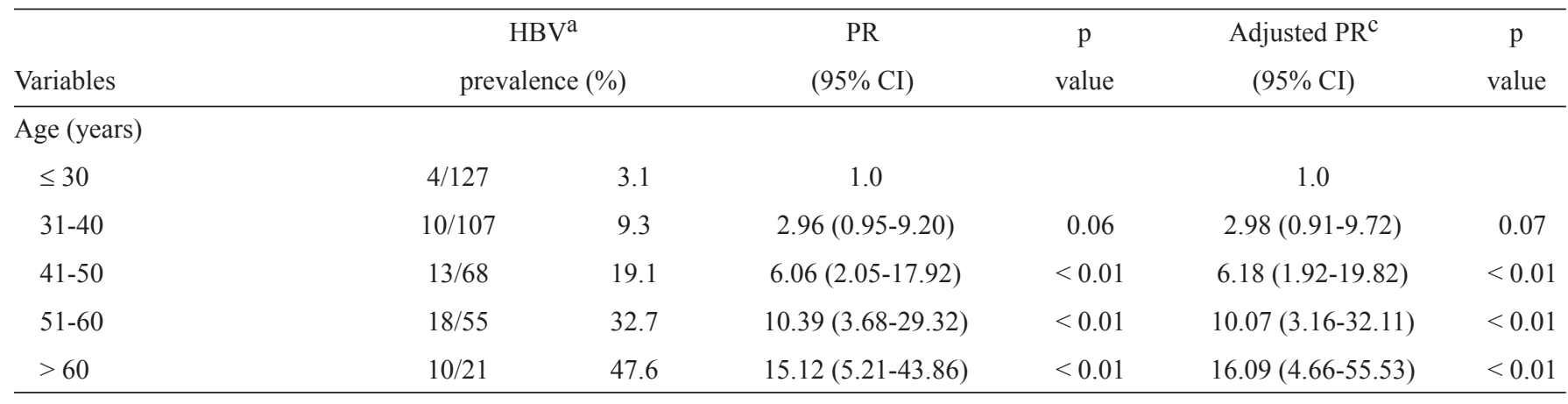

Gender

\begin{tabular}{|c|c|c|c|c|c|c|}
\hline female & $20 / 235$ & 12.8 & 1.0 & & 1.0 & \\
\hline male & $25 / 143$ & 17.5 & $1.37(0.84-2.23)$ & 0.21 & $0.79(0.45-1.39)$ & 0.43 \\
\hline \multicolumn{7}{|c|}{ Schooling (years) } \\
\hline$>8$ & $7 / 103$ & 6.8 & 1.0 & & 1.0 & \\
\hline $4-8$ & $19 / 156$ & 12.2 & $1.80(0.79-4.14)$ & 0.16 & $1.75(0.81-3.80)$ & 0.16 \\
\hline$<4$ & $29 / 119$ & 24.4 & $3.58(1.64-7.84)$ & $<0.01$ & $1.75(0.79-3.86)$ & 0.17 \\
\hline
\end{tabular}

Length of profession (years)

\begin{tabular}{|c|c|c|c|c|c|c|}
\hline$\leq 1$ & $27 / 195$ & 13.8 & 1.0 & & & \\
\hline $2-10$ & $20 / 140$ & 14.3 & $0.94(0.55-1.62)$ & 0.84 & & \\
\hline$>10$ & $8 / 43$ & 18.6 & $1.29(0.63-2.64)$ & 0.48 & - & - \\
\hline \multicolumn{7}{|c|}{ Waste sharps/needle accidents ${ }^{b}$} \\
\hline no & $27 / 197$ & 13.7 & 1.0 & & & \\
\hline yes & $28 / 179$ & 15.6 & $0.93(0.57-1.53)$ & 0.79 & - & - \\
\hline \multicolumn{7}{|c|}{ Blood transfusion ${ }^{b}$} \\
\hline no & $46 / 329$ & 14.0 & 1.0 & & & \\
\hline yes & $9 / 48$ & 18.8 & $1.34(0.70-2.56)$ & 0.38 & - & - \\
\hline \multicolumn{7}{|l|}{ Tattoo } \\
\hline no & $43 / 307$ & 14.0 & 1.0 & & & \\
\hline yes & $12 / 71$ & 16.9 & $1.2(0.67-2.17)$ & 0.53 & - & - \\
\hline \multicolumn{7}{|c|}{ Illicit drug use } \\
\hline no & $40 / 307$ & 13.0 & 1.0 & & 1.0 & \\
\hline yes & $15 / 71$ & 21.1 & $1.59(0.93-2.72)$ & 0.09 & $2.05(1.15-3.68)$ & 0.01 \\
\hline \multicolumn{7}{|c|}{ Incarceration ${ }^{b}$} \\
\hline no & $38 / 310$ & 12.3 & 1.0 & & 1,0 & \\
\hline yes & $16 / 65$ & 24.6 & $2.0(1.19-3.37)$ & $<0.01$ & $1.23(0.69-2.22)$ & 0.48 \\
\hline \multicolumn{7}{|c|}{$\begin{array}{l}\text { Unprotected sex with } \\
\text { multiple partners }(>5)\end{array}$} \\
\hline no & $26 / 223$ & 11.7 & 1.0 & & 1.0 & \\
\hline yes & $29 / 155$ & 18.7 & $1.60(0.98-2.61)$ & 0.06 & $1.52(0.87-2.67)$ & 0.14 \\
\hline \multicolumn{7}{|l|}{ STDs $^{b}$} \\
\hline no & $35 / 286$ & 12.2 & 1.0 & & 1.0 & \\
\hline yes & $20 / 78$ & 25.6 & $2.09(1.28-3.42)$ & $<0.01$ & $1.23(0.76-2.02)$ & 0.39 \\
\hline
\end{tabular}

95\% CI: 95\% confidence interval; PR: prevalence ratio; HBV: hepatitis B virus; STDs: sexually transmitted diseases. ${ }^{\mathrm{a}} \mathrm{HBV}-\mathrm{vaccinated}$ individuals were excluded $(n=378)$. ${ }^{b}$ The total represents the number of individuals who answered the question. ${ }^{\mathrm{c}}$ Adjusted for age, gender, schooling, history of illicit drug use, incarceration, unprotected sex with multiple partners and history of STDs. 


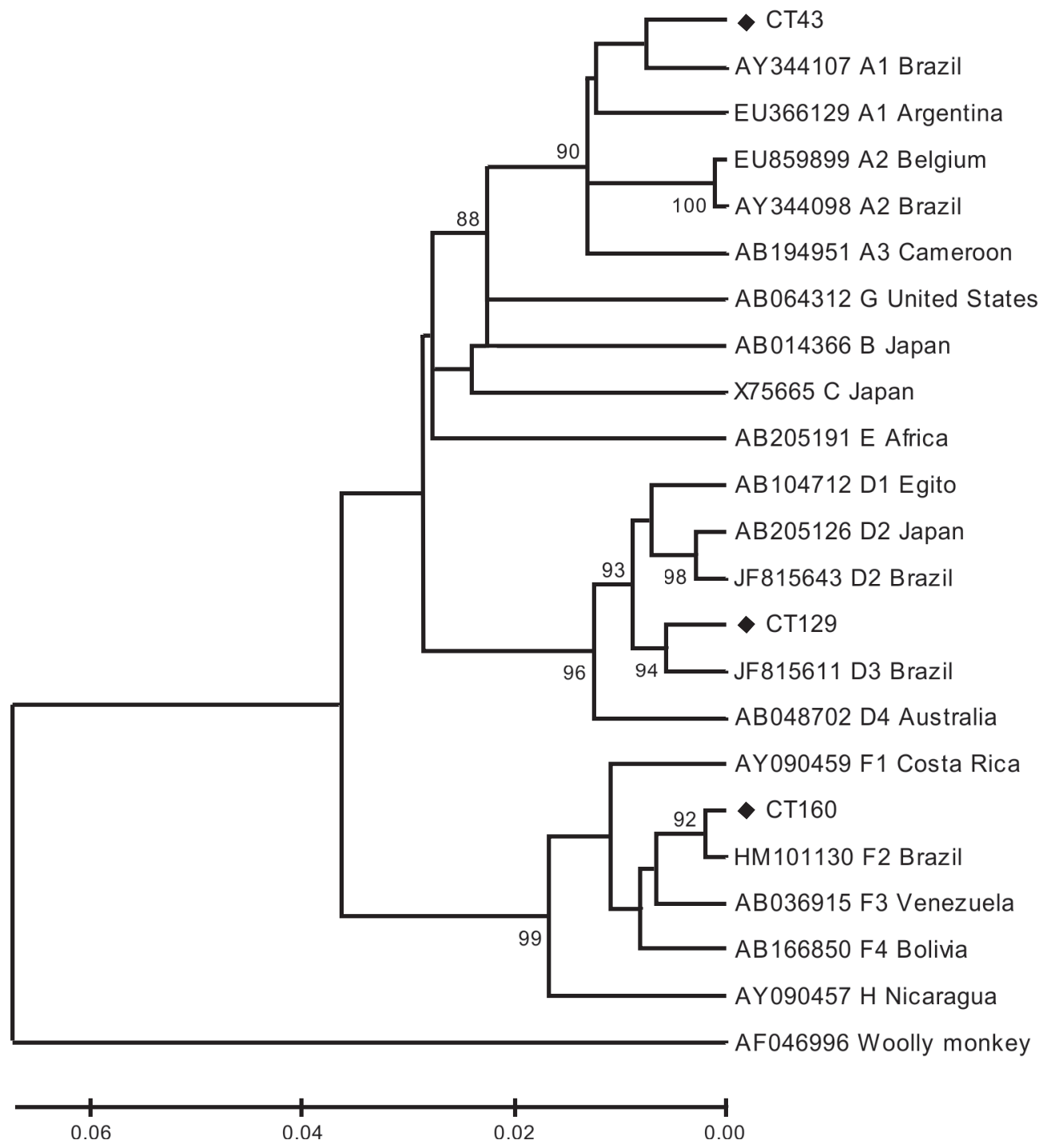

FIGURE 1 - Phylogenetic tree analysis based on nucleotide sequencing of the small S region of hepatitis B virus. The samples described in this study $(\bullet \mathrm{CT} 43$, $-\mathrm{CT} 129$ and $-\mathrm{CT}$ 160) and 19 representative strains of HBV genotypes (A-H) from GenBank, identified by accession number, genotype/subgenotype and country of origin, were included in the tree. The genome of woolly monkey HBV (GenBank AF046996) was utilized as an out-group. The tree was constructed using the neighbor-joining (NJ) method. The bootstrap values were calculated for 1,025 replicas, and consensus percentages are shown on the tree.

The three HBsAg-positive samples also possessed anti-HBe reactivity. Of these, two samples were positive for HBV DNA. Among the 52 HBsAg-negative/anti-HBc-positive samples (42 anti-HBc/anti-HBs and 10 anti-HBc only), one anti-HBc/antiHBs-reactive sample was HBV DNA positive, resulting in an occult $\mathrm{HBV}$ infection rate of $1.9 \%$. In the genotyping analysis, all three HBV DNA-positive samples could be sequenced in the $\mathrm{S}$ region. Using a phylogenetic tree analysis of the $S$ region (Figure 1), the HBV genotypes/subgenotypes A/A1, D/D3 and F/F2 were identified.

\section{DIsCusSION}

The prevalence of HBV infection found among recyclable waste collectors was 2.4-fold higher than that reported in a population-based study in the same region $(5.3 \%$; $95 \%$
CI: 4.6-6.1 $)^{19}$. Compared with the prevalence in other Brazilian populations, the prevalence determined in this study was within the confidence interval range recorded for patients attending an STD clinic (13\%; 95\% CI: 10.0-16.5) $)^{20}$, non-injection drug users (14\%; $95 \%$ CI: $11.7-16.5)^{21}$ and individuals reporting to an HIV testing and counseling center $(14.6 \%$; $95 \%$ CI: 11.2-18.0 $)^{22}$. Nevertheless, relative to other reported data on recyclable waste collectors, the prevalence found in the present study was lower than that observed in Santos, Brazil (34.4\%; 95\% CI: 28.5-40.2 $)^{14,15}$. This difference may reflect differences in the rates of risky behaviors between the studied groups in Goiânia and Santos.

In the present study, an age over 40 years was significantly associated with $\mathrm{HBV}$ infection. As described elsewhere, age may be a proxy for lifetime exposure, indicating that over time, there 
is a cumulative risk of acquiring an HBV infection linked to sexual and parenteral exposures ${ }^{19,23}$. This possibility is supported by the observation that illicit drug use was associated with increased HBV prevalence in the studied population. Among the 71 recyclable waste collectors who reported illicit drug use, the majority had used non-injection drugs only $(88.7 \%$; $63 / 71)$ (data not shown). Although the factors leading to an increased risk of hepatitis B in non-injection drug users are not well established, $\mathrm{HBV}$ infection is associated with unsafe sexual behavior and blood-borne transmission ${ }^{21,24}$.

Other authors have reported that sexual transmission seems to be an important HBV transmission route in areas of low endemicity ${ }^{19,25,26}$. In the current study, however, unprotected sex with multiple partners and previous STDs were not significantly associated with HBV infection in the adjusted analysis, even though previous STDs were associated in the bivariate analysis. Moreover, unprotected sex with multiple partners was marginally associated. Risky sexual behaviors among recyclable waste collectors in Santos were also studied by Rozman et al. ${ }^{15}$. It should be stressed that most preventative policies related to STDs target groups with higher risks of exposure that do not include recyclable waste collectors.

A low schooling level and a history of incarceration were also associated with HBV infection in the bivariate analysis. As observed elsewhere, the level of education among recyclable waste collectors was low ${ }^{7-9,12,15}$. In fact, nearly $73 \%$ of the study population had less than 8 years of schooling. Those individuals who had been incarcerated also had limited educational opportunities and pervasive social health problems. These factors have been reported to be predictors of HBV infection and seem to be common in socially vulnerable populations ${ }^{17,27-29}$.

Although occupational exposure to waste was not associated with HBV infection, a high frequency $(47.6 \% ; 179 / 376)$ of sharps and needle accidents was observed among recyclable waste collectors (Table 2), as well as a low adherence to using gloves $(63.6 \%)$ and other personal protective equipment (data not shown). These findings support previously reported data, reinforcing the importance of establishing educational and health policies that address the safety of this population ${ }^{6,7,9,11,15}$.

The present study provides data describing the prevalence of occult HBV infection in recyclable waste collectors. Although no comparable data have been published, the proportion of occult HBV infection identified was similar to that reported in a community of African origin (1.7\%), which utilized similar methods for the detection of HBV DNA ${ }^{29}$. The HBV genotypes/ subtypes $\mathrm{A} / \mathrm{A} 1, \mathrm{D} / \mathrm{D} 3$ and $\mathrm{F} / \mathrm{F} 2$ were identified in the three HBV DNA-positive serum samples, consistent with those circulating in the central-western region and other regions in Brazil 19,30,31. Furthermore, it is noteworthy that the identified genotype F/subtype F2 may indicate movement of the population from the Amazon region, where the frequency of this genotype/subtype is considerable ${ }^{30,32}$.

In addition to expanding hepatitis B vaccination, only $12.3 \%$ of the study population had a serological profile indicative of previous $\mathrm{HBV}$ vaccination, and $74.9 \%$ were susceptible to HBV infection. In addition, it is worth noting that only $29.7 \%$
(27/91) of the recyclable waste collectors who were eligible for free hepatitis B vaccination in Brazil (during the study period, all individuals under 24 years of age) had serological evidence of vaccination (data not shown), indicating low hepatitis B immunization coverage. The Brazilian Immunization Program recommends the administration of the hepatitis $\mathrm{B}$ vaccine to newborns, children and, more recently, adults under 50 years of age as well as to high-risk individuals, not including recyclable waste collectors.

These results must be considered in the context of the study's limitations. This was a cross-sectional study, and the behavioral findings were based on self-reports. Although this study included $99.8 \%$ of the recyclable waste pickers who were participating in all recycling cooperatives in Goiânia City, central Brazil, this group does not represent all recyclable waste pickers in this city. Moreover, given that there is a lack of available data on the epidemiology of HBV infection among recyclable waste pickers in central Brazil, these data provide valuable insight into this topic.

In conclusion, this study revealed that the HBV prevalence found among recyclable waste collectors was higher than that reported in a population-based study in the same region. In addition, the low vaccination rates and the presence of risky behaviors found in the study population highlight a need for improved health awareness and hepatitis B prevention programs in recycling cooperatives in central Brazil.

\section{CONFLICT OF INTEREST}

The authors declare that there is no conflict of interest.

\section{FINANCIAL SUPPORT}

This study was supported by the Conselho Nacional de Desenvolvimento Cientifico e Tecnológico (CNPq) and Fundação de Amparo à Pesquisa do Estado de Goiás (FAPEG).

\section{REFERENCES}

1. Franco E, Bagnato B, Marino MG, Meleleo C, Serino L, Zaratti L. Hepatitis B: Epidemiology and prevention in developing countries. World J Hepatol 2012; 4:74-80.

2. World Health Organization (WHO) [Internet]. Hepatitis B Fact sheet $\mathrm{n}^{\circ}$ 204 July 2012. [Cited 2013 January 22]. Available at: http://www.who. $\mathrm{int} /$ mediacentre/factsheets/fs204/en/.htm.

3. Said ZN. An overview of occult hepatitis B virus infection. World J Gastroenterol 2011; 17:1927-1938.

4. Kao JH. Molecular epidemiology of hepatitis B virus. Korean J Intern Med 2011; 26:255-261.

5. Compromisso Empresarial para Reciclagem (CEMPRE) [Internet]. Política Nacional de Resíduos Sólidos. Agora é Lei: Novos desafios para poder público, empresas, catadores e população 2010. [Cited 2012 December 14]. Available at: http://www.cempre.org.br/download/ pnrs_002.pdf.

6. Porto MF, Juncá DC, Gonçalves RS, Filhote MI. Lixo, trabalho e saúde: um estudo de caso com catadores em um aterro metropolitano no Rio de Janeiro, Brasil. Cad Saude Publica 2004; 20:1503-1514. 
7. Silva MC, Fassa AG, Siqueira CE, Kriebel D. World at work: Brazilian ragpickers. Occup Environ Med 2005; 62:736-740.

8. Medeiros LFR, Macêdo KB. Catador de material reciclável: uma profissão para além da sobrevivência? Psicol Soc 2006; 18:62-71.

9. Almeida JR, Elias ET, Magalhães MA, Vieira AJD. Efeito da idade sobre a qualidade de vida e saúde dos catadores de materiais recicláveis de uma associação em Governador Valadares, Minas Gerais, Brasil. Cien Saude Colet 2009; 14:2169-2179.

10. Kuijer PP, Sluiter JK, Frings-Dresen MH. Health and safety in waste collection: Towards evidence-based worker health surveillance. Am J Ind Med 2010; 53:1040-1064.

11. Gutberlet J, Baeder AM, Pontuschka NN, Felipone SM, Santos TL. Participatory research revealing the work and occupational health hazards of cooperative recyclers in Brazil. Int J Environ Res Public Health 2013; 10:4607-4627.

12. Auler F, Nakashima AT, Cuman RK. Health conditions of recyclable waste pickers. J Community Health 2014; 39:17-22.

13. Rachiotis G, Papagiannis D, Markas D, Thanasias E, Dounias G, Hadjichristodoulou C. Hepatitis B virus infection and waste collection: prevalence, risk factors, and infection pathway. Am J Ind Med 2012; 55:650-655.

14. Rozman MA, Alves IS, Porto MA, Gomes PO, Ribeiro NM, Nogueira LA, et al. HIV and related infections in a sample of recyclable waste collectors of Brazil. Int J STD AIDS 2007; 18:653-654.

15. Rozman MA, Alves IS, Porto MA, Gomes PO, Ribeiro NM, Nogueira LA, et al. HIV infection and related risk behaviors in a community of recyclable waste collectors of Santos, Brazil. Rev Saude Publica 2008; 42:838-843.

16. Niel C, Koper PC, Visser AG, Sipkema D, Levendag PC. Genetic diversity of hepatitis B virus strains isolated in Rio de Janeiro, Brazil. Int J Radiat Oncol Biol Phys 1994; 44:180-186.

17. Motta-Castro AR, Martins RM, Yoshida CF, Teles SA, Paniago AM, Lima KM, et al. Hepatitis B virus infection in isolated Afro-Brazilian communities. J Med Virol 2005; 77:188-193.

18. Motta-Castro AR, Martins RM, Araujo NM, Niel C, Facholi GB, Lago BV, et al. Molecular epidemiology of hepatitis B virus in an isolated AfroBrazilian community. Arch Virol 2008; 153:2197-2205.

19. Pereira LM, Martelli CM, Merchán-Hamann E, Montarroyos UR, Braga MC, Lima ML, et al. Population-based multicentric survey of hepatitis B infection and risk factor differences among three regions in Brazil. Am J Trop Med Hyg 2009; 81:240-247.
20. Oliveira LH, Silva IR, Xavier BL, Cavalcanti SM. Hepatitis B infection among patients attending a sexually transmitted diseases clinic in Rio de Janeiro, Brazil. Mem Inst Oswaldo Cruz 2001; 96:635-640.

21. Ferreira RC, Rodrigues FP, Teles SA, Lopes CL, Motta-Castro AR, Novais AC, et al. Prevalence of hepatitis B virus and risk factors in Brazilian noninjecting drug users. J Med Virol 2009; 81:602-629.

22. Monteiro MR, Passos AD, Figueiredo JF, Gaspar AM, Yoshida CF. Marcadores sorológicos da hepatite $\mathrm{B}$ em usuários de um centro de testagem para o HIV. Rev Soc Bras Med Trop 2001; 34:53-59.

23. Lewis-Ximenez LL, do O KM, Ginuino CF, Silva JC, Schatzmayr HG, Stuver S, et al. Risk factors for hepatitis B virus infection in Rio de Janeiro, Brazil. BMC Public Health 2002; 2:26.

24. Quaglio G, Lugoboni F, Mezzelani P, Des Jarlais DC, Lechi A. Hepatitis vaccination among drug users. Vaccine 2006; 24:2702-2709.

25. Miranda AE, Figueiredo NC, Schmidt R, Page-Shafer K. A populationbased survey of the prevalence of HIV, syphilis, hepatitis B and hepatitis $\mathrm{C}$ infections, and associated risk factors among young women in Vitória, Brazil. AIDS Behavior 2008; 12 (Suppl IV):25-31.

26. Matos SB, Jesus AL, Pedroza KC, Sodre HR, Ferreira TL, Lima FW. Prevalence of serological markers and risk factors for blood borne pathogens in Salvador, Bahia state, Brazil. Epidemiol Infect 2012; 15: 1-7.

27. Porto SO, Cardoso DD, Queiróz DA, Rosa H, Andrade AL, Zicker F, et al. Prevalence and risk factors for HBV infection among street youth in Central Brazil. J Adolesc Health 1994; 15:577-581.

28. Matos MA, Martins RM, Silva França DD, Pessoni GC, Ferreira RC, Matos MA, et al. Epidemiology of hepatitis B virus infection in truck drivers in Brazil, South America. Sex Transm Infect 2008; 84:386-389.

29. Matos MA, Reis NR, Kozlowski AG, Teles SA, Motta-Castro AR, Mello FC, et al. Epidemiological study of hepatitis A, B and C in the largest Afro-Brazilian isolated community. Trans R Soc Trop Med Hyg 2009; 103:899-905.

30. Mello FC, Souto FJ, Nabuco LC, Villela-Nogueira CA, Coelho HS, Franz HC, et al. Hepatitis B virus genotypes circulating in Brazil: molecular characterization of genotype F isolates. BMC Microbiol 2007; 7:103.

31. Santos AO, Alvarado-Mora MV, Botelho L, Vieira DS, Pinho JR, Carrilho FJ, et al. Characterization of hepatitis B virus (HBV) genotypes in patients from Rondônia, Brazil. Virol J 2010; 7:315.

32. Mello FC, Araujo OC, Lago BV, Motta-Castro AR, Moraes MT, Gomes SA, Bello G, et al. Phylogeography and evolutionary history of hepatitis B virus genotype F in Brazil. Virol J 2013; 10:236. 